\title{
Tpack dalam Pembelajaran Matematika Online di Masa Pandemi
}

\author{
Nahdah Khairun Najibah ${ }^{1}$, Ellis Salsabila², Meiliasari ${ }^{3}$ \\ Universitas Negeri Jakarta ${ }^{1,2,3}$ \\ Email: nahdahkhairun@gmail.com¹, ellissalsabila@yahoo.com² ${ }^{2}$,meiliasari@unj.ac.id³
}

\begin{abstract}
Abstrak. Penulisan artikel ini menggunakan metode studi literatur yang berfokus pada peranan TPACK serta upaya peningkatannya dalam pembelajaran matematika online di masa pandemi. Penggunaan ICT dalam pembelajaran matematika online menjadi tantangan tersendiri bagi guru. Maka dibutuhkan peningkatan kompetensi guru salah satunya melalui peningkatan TPACK. TPACK memiliki peranan penting terutama untuk meningkatkan pembelajaran serta capaian belajar siswa. Upaya yang dapat dilakukan guru untuk meningkatan TPACK dalam pembelajaran matematika diantaranya mengoptimalkan penggunaan platform Guru Belajar \& Berbagi, turut serta dalam kegiatan workshop dan webinar, serta melakukan lesson study.
\end{abstract}

\section{Kata Kunci: TPACK, Pembelajaran Matematika Online, Lesson Study}

\begin{abstract}
The writing of this article is using a literature review method that focuses on the role of TPACK and how to improve online learning mathematics during a pandemic. The use of ICT in online learning mathematics is challenging for teachers. So it is necessary to increase teacher's competence, including TPACK. TPACK has an important role in online learning mathematics, especially to improve instructional and student learning outcomes. Efforts that can be made by teachers to increase TPACK in learning mathematics include optimizing the use of the platform Guru Belajar \& Berbagi, participating in workshops and webinars, and conducting lesson study
\end{abstract}

\section{Keywords: $\quad$ TPACK, Mathematics Online Learning, Lesson Study.}

\section{A. Pendahuluan}

Pemilihan pembelajaran online di masa pandemi telah terbukti menjadi salah satu bentuk pencegahan paling efektif yang diberlakukan oleh pemerintah sebagai upaya pencegahan penyebaran virus (Hussein et al., 2020; Moosa, 2020). Dalam hal ini, penggunaan Information and Communication Technologies (ICT) dalam Electronic learning (E-Learning) menjadi pilihan terbaik untuk melanjutkan pembelajaran pada masa pandemi (Mailizar et al., 2020). Penggunaan teknologi yang efektif dan tepat dalam pembelajaran online dapat membuat siswa belajar dengan lebih baik (Mulenga \& Marbán, 2020; Perienen, 2020). Selain itu, hal tersebut berdampak pada efektivitas biaya, waktu, keamanan, dan kenyamanan bukan hanya bagi siswa, tetapi juga bagi guru. Guru memiliki waktu tambahan karena dapat menghemat waktu perjalanan serta mendapatkan kenyamanan karena pengajaran dilakukan di rumah (Cassibba et al., 2021; Hussein et al., 2020).

Meski menjadi pilihan terbaik pada masa pandemi, pelaksanaan pembelajaran online tetap harus memperhatikan berbagai macam tantangan yang ada, khususnya dalam pembelajaran matematika. Misalnya, pada pembelajaran matematika konvensional papan tulis biasa digunakan sebagai media untuk menuliskan konsep matematika yang berisikan simbolsimbol matematis. Penulisan persamaan matematika pada perangkat yang tersedia menjadi tantangan bagi guru dalam proses pengajaran matematika (Wong, 2014). Dengan demikian, dalam penerapan pembelajaran online, guru kehilangan "zona nyaman"nya (Cassibba et al., 2021). Tantangan tersebut tentunya dapat mempengaruhi pelaksanaan pembelajaran online yang berdampak pada capaian belajar matematika siswa.

Di Indonesia sendiri, pembelajaran jarak jauh dengan metode online berdampak pada penurunan capaian belajar siswa (Kemendikbud, 2021). Penurunan ataupun peningkatan capaian belajar matematika dalam pembelajaran online dapat dipengaruhi oleh banyak faktor, 
salah satunya dari faktor guru. Keterampilan profesional guru dan kualitas pembelajaran yang disajikan merupakan faktor penting yang dapat mempengaruhi capaian siswa (Baier \& Kunter, 2020). Berdasarkan Peraturan Menteri Pendidikan Nasional Republik Indonesia no.16 tahun 2007 tentang standar kualifikasi akademik dan kompetensi guru, guru perlu memiliki kompetensi profesional yakni: 1) Menguasai meteri, struktur, dan pola pikir keilmuan yang mendukung mata pelajaran yang diampu; 2) Menguasai standar kompetensi dan kompetensi dasar mata pelajaran yang diampu; 3) Mengembangkan materi pembelajaran yang diampu; 4) Mengembangkan keprofesionalan secara berkelanjutan dengan melakukan tindakan reflektif; dan 5) Memanfaatkan teknologi informasi dan komunikasi untuk mengembangkan diri. Lima kompetensi profesional tersebut menandakan bahwa guru perlu memiliki pengetahuan dan penguasaan teknologi, pengajaran dan pembelajaran (pedagogi), dan mata pelajaran (konten) atau dikenal sebagai Technological and pedagogical content knowledge (TPACK).

TPACK mencakup integrasi antara mata pelajaran (konten), teknologi, dan pemahaman terkait pengajaran dan pembelajaran (pedagogi) (Brinkley-Etzkorn, 2018). Pembelajaran online sangat erat kaitannya dengan penggunaan teknologi. Oleh karenanya, Pengajaran dan pembelajaran online membutuhkan kompetensi yang perlu ditingkatkan (Mulenga \& Marbán, 2020). Kompetensi tersebut termasuk pada pengetahuan mengenai pengintegrasian teknologi, pedagogi, dan konten. Penulisan artikel ini bertujuan untuk mendeskripsikan TPACK dan perananannya, serta upaya peningkatannya dalam pembelajaran matematika. Temuan dalam artikel ini diharapkan dapat memperkaya literatur TPACK, serta menjadi referensi upaya peningkatan TPACK dalam pembelajaran matematika sekolah. Oleh karena itu, pada artikel ini dirumuskan pertanyaan sebagai berikut: Apa itu TPACK? Bagaimana peranan TPACK dalam pembelajaran matematika? Apa saja upaya yang dapat dilakukan untuk menunjang peningkatan TPACK dalam pembelajaran matematika pada masa pandemi?.

\section{B. Metodologi Penelitian}

Metode yang digunakan dalam penulisan artikel ini adalah studi literatur. Penulisan artikel ini dimulai dengan mencari artikel internasional dan nasional melalui mendeley, sciencedirect, dan google cendekia. Topik yang menjadi fokus pencarian diantaranya adalah "Online learning mathematics during covid-19", "Online learning mathematics", "TPACK", "TPACK in mathematics education", "The role of TPACK", dan "Lesson Study".

Berdasarkan hasil pencarian, penulis memperoleh 89 artikel. Selanjutnya penulis memilah artikel dengan cara mengakses situs scimagojr.com dan sinta.ristekbrin.go.id untuk mengetahui status indeks artikel yang telah diperoleh, hal ini dikarenakan penulis ingin fokus mengkaji artikel yang terindeks scopus dan sinta. Artikel yang tidak masuk kategori tidak digunakan dalam penulisan artikel ini, dari hasil pencarian indeks diperoleh 59 artikel (23 artikel mengenai pembelajaran matematika online dan pembelajaran matematika online pada masa pandemi, 6 artikel menganai lesson study, 30 artikel mengenai TPACK) yang memenuhi kriteria scopus dan sinta. Selanjutnya artikel yang telah dipilah dilakukan kajian lebih lanjut.

Penulis menemukan bahwa teori utama pada topik TPACK pertama kali diusung oleh Shulman (1986) mengenai PCK, kemudian dikembangkan kembali oleh Koehler \& Mishra (2006) yang menambahkan unsur teknologi pada PCK yang dikenal sebagai TPACK. Maka dari itu, penulis mencari teori utama dengan bantuan google. Penulis menggunakan kata kunci nama penulis beserta judul yang diperoleh dari daftar referensi artikel-artikel yang telah dipilah. Penulis menemukan teori utama berasal dari handbook. 


\section{Hasil Penelitian dan Pembahasan \\ 1. TPACK}

Konsep TPACK (Technological Pedagogical Content Knowledge) pertama kali diperkenalkan oleh Koehler \& Mishra (2006). Koehler \& Mishra mengembangkan framework TPACK berdasarkan ide PCK (Pedagogical Content Knowledge) yang telah dikembangkan terlebih dulu oleh Shulman (1986). Penambahan teknologi pada konteks PCK diperkenalkan sebagai suatu cara untuk mendukung dan meningkatkan strategi yang digunakan dalam kelas. Pada TPACK, terdapat tujuh komponen utama yakni TK (Technological Knowledge), PK (Pedagogical Knowledge), CK (Content Knowledge), TPK (Techological Pedagogical Knowledge), TCK (Techological Content Knowledge), PCK (Pedagogical Content Knowledge), dan TPACK (Techological Pedagogical Content Knowledge). Berikut merupakan framework TPACK (Koehler et al., 2014):

a. TK (Technology Knowledge)

TK merupakan pengetahuan terkait teknologi baik secara tradisional maupun teknologi terbaru yang dapat diintegrasikan pada kurikulum

b. PK (Pedagogical Knowledge)

PK merupakan pengetahuan terkait teknik, strategi, dan metode pembelajaran untuk meningkatkan pembelajaran siswa

c. CK (Content Knowledge)

CK merupakan pengetahuan terkait subjek yang diajarkan oleh guru

d. TCK (Techological Content Knowledge)

TCK merupakan pengetahuan terkait hubungan antara teknologi dan konten

e. TPK (Techological Pedagogical Knowledge)

TPK merupakan pengetahuan guru terkait pemahaman teknologi yang dapat mendukung dan menguatkan pembelajaran

f. PCK (Pedagogical Content Knowledge)

PCK merupakan pemahaman tentang bagaimana topik, permasalahan, atau isu diatur, direpresentasikan, dan diadaptasi untuk kemampuan dan minat siswa yang beagam, serta tersampaikan dalam pembelajaran

g. TPACK (Techological Pedagogical Content Knowledge)

TPACK merupakan pengetahuan tentang hubungan yang kompleks antara teknologi, pedagogi, dan konten yang memungkinkan guru untuk membangun strategi pengajaran yang tepat.

\section{Peranan TPACK dalam Pembelajaran Matematika Online}

Tantangan penggunaan teknologi dalam pembelajaran online erat kaitannya dengan pengajaran matematika dikarenakan dalam pelaksanaannya melibatkan penggunaan rumus dan simbol matematika (Cassibba et al., 2021). Selain itu, pengelolaan pembelajaran online melibatkan suatu sistem yang tidak sederhana (Mailizar et al., 2020; Marbán et al., 2021). Pengelolaannya perlu mempertimbangkan pemilihan teknologi, metodologi, dan rancangan pembelajaran yang tepat agar tujuan pembelajaran dapat tercapai (Cassibba et al., 2021; Fujita, 2020; Hussein et al., 2020; Mulenga \& Marbán, 2020). Dalam hal ini, guru ataupun calon guru matematika perlu mengetahui bagaimana pengintegrasian teknologi dengan materi yang akan disampaikan agar tujuan pembelajaran dapat tercapai.

Pemahaman guru dan calon guru terkait TPACK dapat membantu meningkatkan efisiensi pengintegrasian teknologi selama pengajaran (Habibi et al., 2020). Selain itu, guru matematika yang memiliki pengetahuan terkait pengintegrasian teknologi memiliki pengaruh positif terhadap self efficacy saat menggunakan teknologi dalam kegiatan belajar mengajar (Bakar et al., 2020). Guru yang memiliki self efficacy yang tinggi dalam TPACK dapat menggunakan 
teknologi secara tepat dalam pembelajaran. Penggunaan strategi dan teknologi yang tepat dalam pembelajaran, dan akan meningkatkan capaian belajar siswa. (Akturk et al., 2019).

\section{Upaya Peningkatan TPACK dalam Pembelajaran Matematika di Masa Pandemi}

TPACK memiliki peranan penting dalam pembelajaran matematika. Oleh karenanya perlu upaya peningkatan TPACK, khususnya bagi guru matematika di Indonesia (Mailizar et al., 2020; Ng, 2011). Beberapa upaya yang dapat dilakukan guru untuk meningkatkan TPACK diantaranya:

1. Mengoptimalkan penggunaan platform yang disediakan oleh Kementerian pendidikan, kebudayaan, riset, dan teknologi yakni Guru Belajar \& Berbagi yang menyediakan berbagai macam pelatihan sebagai upaya peningkatan kompetensi guru dalam TPACK. Hal tersebut dapat membantu guru dalam mengembangkan kompetensinya terkait penggunaan media untuk tujuan pembelajaran (Ndongfack, 2015)

2. Mengikuti berbagai webinar dan workshop yang diadakan oleh berbagai organisasi yang berfokus pada matematika, diantaranya Matematika Nusantara, SEAQiM (SEAMEO Regional Centre for QITEP in Mathematics), dan MGMP (Musyawarah Guru Mata Pelajaran) Matematika.

3. Melakukan Lesson study (LS). Pembelajaran matematika di masa pandemi sebaiknya melibatkan kolaborasi antar guru untuk dapat memberikan saran, masukan, hingga pengetahuan terkait teknologi, pedagogi, dan konten dalam praktik mengajar. LS memungkinkan guru untuk meningkatkan kompetensi pengajaran matematika serta saling berkolaborasi dan berbagi pengetahuan terkait praktik mengajar. LS merupakan model pengembangan profesional bagi guru, dimana guru saling berkolaborasi dalam mengembangkan suatu penelitian, mengkaji kurikulum kemudian membuat perencanaan, mengimplementasikan, mengamati, dan merefleksikan penelitian pembelajarannya untuk meningkatkan praktik pengajaran yang berdampak pada pembelajaran siswa (Shuilleabhain \& Seery, 2017; Takahashi \& McDougal, 2016)

\section{Kesimpulan}

Pembelajaran matematika online pada masa pandemi tidak terlepas dari berbagai tantangan, salah satu tantangan yang dihadapi oleh guru yakni penggunaan ICT dalam pembelajaran. Penggunaan ICT dalam pembelajaran perlu diimbangi dengan peningkatan kompetensi guru, salah satunya melalui upaya peningkatan TPACK. TPACK memiliki peranan yang cukup penting dalam pembelajaran, diantaranya dapat mempengaruhi capaian siswa. Beberapa upaya yang dapat dilakukan untuk meningkatkan TPACK guru dalam pembebelajaran dan pengajaran matematika online diantaranya mengoptimalkan penggunaan platform Guru Belajar \& Berbagi, ikut serta dalam berbagai workshop dan weminar, dan melakukan kolaborasi antar guru untuk memberikan saran dan masukan satu sama lain melalui lesson study. Upaya tersebut sebatas kajian penulis berdasarkan literatur yang ada. Bagi peneliti di masa yang akan datang diharapkan dapat mengkaji secara kuantitatif khususnya pengaruh lesson study terhadap TPACK guru dalam pembelajaran matematika serta capaian belajar matematika siswa.

\section{DAFTAR PUSTAKA}

Akturk, A. O., Ozturk, H. S., Ozturk, S., \& Tpack, H. T. (2019). Teachers ' TPACK Levels and Students 'Self- efficacy as Predictors of Students ' Academic Achievement To cite this 
article: Teachers 'TPACK Levels and Students' Self-efficacy as Predictors of Students 'Academic Achievement.

Baier, F., \& Kunter, M. (2020). Construction and validation of a test to assess (pre-service) teachers' technological pedagogical knowledge (TPK). Studies in Educational Evaluation, 67(October), 100936. https://doi.org/10.1016/j.stueduc.2020.100936

Bakar, N. S. A., Maat, S. M., \& Rosli, R. (2020). Mathematics Teacher's Self-Efficacy of Technology Integration and Technological Pedagogical Content Knowledge. 11(2), 259276.

Brinkley-Etzkorn, K. E. (2018). Learning to teach online: Measuring the influence of faculty development training on teaching effectiveness through a TPACK lens. Internet and Higher Education, 38(April), 28-35. https://doi.org/10.1016/j.iheduc.2018.04.004

Cassibba, R., Ferrarello, D., Mammana, M. F., Musso, P., Pennisi, M., \& Taranto, E. (2021). Teaching mathematics at distance: A challenge for universities. Education Sciences, 11(1), 1-20. https://doi.org/10.3390/EDUCSCI11010001

Fujita, N. (2020). Transforming online teaching and learning: towards learning design informed by information science and learning sciences. Information and Learning Science, 121(78), 503-511. https://doi.org/10.1108/ILS-04-2020-0124

Habibi, A., Yusop, F. D., \& Razak, R. A. (2020). The role of TPACK in affecting pre-service language teachers' ICT integration during teaching practices: Indonesian context. Education and Information Technologies, 25(3), 1929-1949. https://doi.org/10.1007/s10639-019-10040-2

Hussein, E., Daoud, S., Alrabaiah, H., \& Badawi, R. (2020). Exploring undergraduate students' attitudes towards emergency online learning during COVID-19: A case from the UAE. Children and Youth Services Review, 119(August). https://doi.org/10.1016/j.childyouth.2020.105699

Kemendikbud. (2021). Kemendikbud Siapkan Kebijakan Pembelajaran Tatap Muka Terbatas. https://www.kemdikbud.go.id/main/blog/2021/03/kemendikbud-siapkan-kebijakanpembelajaran-tatap-muka-terbatas

Koehler, M. J., \& Mishra, P. (2006). Technological Pedagogical Content Knowledge: A Framework for Teacher Knowledge. Teachers College Record, 108(6), 1017-1054.

Koehler, M. J., Mishra, P., Kereluik, K., Shin, T. S., \& Graham, C. R. (2014). The Technological Pedagogical Content Knowledge Framework. In Handbook of Research on Educational Communications and Technology: Fourth Edition (pp. 1-1005). https://doi.org/10.1007/978-1-4614-3185-5

Mailizar, Almanthari, A., Maulina, S., \& Bruce, S. (2020). Secondary school mathematics teachers' views on e-learning implementation barriers during the COVID-19 pandemic: The case of Indonesia. Eurasia Journal of Mathematics, Science and Technology Education, 16(7). https://doi.org/10.29333/EJMSTE/8240

Marbán, J. M., Radwan, E., Radwan, A., \& Radwan, W. (2021). Primary and secondary students' usage of digital platforms for mathematics learning during the COVID-19 
outbreak: The case of the Gaza strip. Mathematics, 9(2), 1-21. https://doi.org/10.3390/math9020110

Moosa, I. A. (2020). The effectiveness of social distancing in containing Covid-19. Applied Economics, 00(00), 6292-6305. https://doi.org/10.1080/00036846.2020.1789061

Mulenga, E. M., \& Marbán, J. M. (2020). Prospective teachers' online learning mathematics activities in the age of COVID-19: A cluster analysis approach. Eurasia Journal of Mathematics, Science and Technology Education, 16(9). https://doi.org/10.29333/EJMSTE/8345

Ndongfack, M. N. (2015). TPACK Constructs: A Sustainable Pathway for Teachers Professional Development on Technology Adoption. September, 1697-1709.

Ng, D. (2011). Indonesian primary teachers' mathematical knowledge for teaching geometry: Implications for educational policy and teacher preparation programs. Asia-Pacific Journal of Teacher Education, 39(2), 151-164. https://doi.org/10.1080/1359866X.2011.560648

Perienen, A. (2020). Frameworks for ICT Integration in Mathematics Education - A Teacher's Perspective. Eurasia Journal of Mathematics, Science and Technology Education, 16(6). https://doi.org/10.29333/ejmste/7803

Shuilleabhain, A. N., \& Seery, A. (2017). Professional Development in Education Enacting curriculum reform through lesson study: a case study of mathematics teacher learning. Professional Development in Education, 5257(March), 1-15. https://doi.org/10.1080/19415257.2017.1280521

Shulman, L. S. (1986). Those Who Understand: Knowledge Growth in Teaching. Educational Researcher, 15(2), 4-14.

Takahashi, A., \& McDougal, T. (2016). Collaborative lesson research: maximizing the impact of lesson study. ZDM, 48(4), 1-14. https://doi.org/10.1007/s11858-015-0752-x.

Wong, G. K. W. (2014). Engaging students using their own mobile devices for learning mathematics in classroom discourse: A case study in Hong Kong. International Journal of Mobile Learning and Organisation, 8(2), 143-165. https://doi.org/10.1504/IJMLO.2014.062352 